\title{
Drought Induced Nepotistic Behaviour in Indian Black Ibis (Pseudibis papillosa) Inhabiting the Arid Zone of Rajasthan, India
}

\author{
K.C. Soni ${ }^{1}$, A.N. Sharma ${ }^{2}$ and V.C. Soni ${ }^{3}$ \\ ${ }^{1}$ Department of Zoology, Lohia P.G. College, Churu (Rajasthan) -331001, India \\ ${ }^{2}$ Principal, Govt. P.G. College, Uniara (Tonk), Rajasthan, India \\ ${ }^{3}$ Department of Bioscience, Saurastra University, Rajkot (Gujarat), India \\ Email:kcsibis@yahoo.com
}

Received: 22.10.2008, Accepted: 01.12.2008

\begin{abstract}
Drought induced nepotistic behaviour in the Indian Black ibis (Pseudibis papillosa) inhabiting the arid zone of Rajasthan has been studied. The aim of the present study is to know about any breeding abnormalities induced in the Indian Black ibis by seasonal tragedy like drought. As such the nepotistic behaviour is not found in the Black ibis (Pseudibis papillosa) during normal season. Drought induces a reduced nesting activity and nepotistic behaviour in the Black ibis inhabiting arid zone. The helper birds (Non breeding birds of the own species) become active during drought to assist breeding pairs of Black ibis in various reproductive activities like feeding of breeding female, nestlings, fledglings and defending the nests. The role of helpers in breeding activities of Black ibis during drought also improves their clutch size, hatching success and fledgling success. The significance of the drought induced nepotistic behaviour in Black ibis in view of Hamilton's theory of kin selection has been discussed.
\end{abstract}

Key words: Nepotistic behaviour, Black ibis, arid zone, Rajasthan, India

\section{Introduction}

An extensive literature exists about helping in birds, where some reproductively mature or immature members of the species temporarily or permanently forego their own reproduction and help other members of their species to reproduce (Skutch, 1935; 1961; Emlen, 1984; 1991; Duplesis, 1993; Ligon and Burt, 2004). Brown's (1987) book is the most extensive review of helping in birds. Nepotistic behaviour where an auxiliary (non breeding adults) assists the breeding pair in rearing their young is known at-least in 300 species of birds (Sridhar and Karanth, 1993). Such behaviour has been recorded in Florida scrub jay (Aphelocoma caerulescense), the Acorn woodpecker (Melanerpes formicivorns), the Pied kingfisher (Ceryle rudis), the Splendid wren (Malurus splendens), the Galapagos mockingbird (Nesomimus parvulus), the Green bee eater (Merops orientalis) and the White fronted bee eater (Merops bullockoides) (Woolfenden and Fitzpatrick, 1984; Gadgkar and Venkataraman, 1990; Sridhar and Karanth, 1993). Duplessis (1993), and Polani and Elgar (1994) have studied cooperative breeding in Greenwood hoopoes and Australian avifauna respectively. Recently Gill (2004) and Round (2006) Have reported cooperative breeding in a Thryothorus wren and in the White-crested laughing thrush (Garrulax leucolophus) respectively. 
Nepotistic behaviour is the behaviour in which individuals other than the genetic parents assist in raising offspring, has been recorded in many bird families. There are several types of cooperation including assisting in feeding nestlings, nest construction, incubation and defence against predators or territory intruders (Brown, 1987). An individual may become a helper instead of dispersing to breed independently due to lack of available territories. In the mean time it can gain indirect fitness benefits by increasing the productivity of the nests of its parents or close relatives (Stacey and Koeing, 1990) and learning the secrets of breeding. Ecology also plays an important role in inducing cooperative breeding in birds as e.g. the drought affects the availability of food and nesting sites. The role of ecology in inducing cooperative breeding in birds has been reported by Arnold and Owens (1999). Proving that cooperation occurs can be particularly difficult in dense tropical forests, where nest visits by adults are infrequent and distinguishing individuals is problematic. Some researchers have also reported $3.2 \%$ ( 308/9872) birds following cooperative breeding (Dow, 1980; Brown, 1987; Arnold and Owens, 1998; Cockburn, 1996; Edwards and Naeem, 1993; Ligon and Burt, 2004), this number is increasing as more detailed studies of a greater range of species are undertaken (Gill, 2004; Round, 2006).

Multiple nest attendance by adults has not been reported previously for any Ciconiiformes species (Skutch, 1999; Kushlan and Hancock, 2005). Only a few reports of cooperative breeding in White ibis are available (Bildstein, 1993; Herring and Gwalik, 2007). Yet no effort has been made to study the cooperative breeding and the effect of helpers on the breeding success of the Black ibis (Pseudibis papillosa). An attempt was therefore made to study the cooperative breeding and the effect of helpers on the breeding success of the Black ibis inhabiting the harsh arid zone of Rajasthan. The aim of the present study is to determine the contribution of helpers in the breeding success of the Black ibis. The role of helpers in the breeding activities of the Black ibis, like feeding of the brooding female, nestling and fledgling, and defending the nests, improves the clutch size, hatching success and fledgling success. The significance of the role of helpers has been discussed.

\section{Materials and methods}

The study was carried out in and around Churu city, Rajasthan, India covering 400 $\mathrm{km}^{2}$ area $\left(29^{\circ} \mathrm{N}, 75^{\circ} \mathrm{E}\right.$; rainfall $325 \mathrm{~mm}$; altitude $286 \mathrm{~m} \mathrm{msl}$ ). The vegetation is arid in nature. The availability of nesting tree to the Black ibis studied was not good enough. The number and distribution of preferential nesting trees like Neem (Azadirachta indica) and Peepal (Ficus religiosa) were poor. Therefore, the nesting sites were limited as compared to the number of breeding pairs. Frequently occurring drought in the arid zone of Rajasthan resulted in scarcity of food also. Due to these factors some reproductively mature individuals of the Black ibis who forgave their own breeding were seen to help the breeding parents. They were observed to help the parents in defending the nest and feeding the chicks. Thus we caught the breeding birds with the help of nest and ringed them to differentiate from the helpers. The male and female were identified on the basis of sexual dimorphism (Soni, 2008). Observations were made with the help of binocular (Olympus 10X50) 


\section{K.C. Soni, A.N. Sharma and V.C. Soni / Our Nature (2008) 6: 47-51}

from dawn to dusk, from a hide, keeping a distance of 25 meters from the nest. The role of ringed male and female parents and un-ringed bird, if any in defending the nest, feeding the nestling and fledgling were recorded. The effect of helper at the nest on the breeding success of the breeding pair was also studied by comparing clutch size, hatching and fledgling success of the nests with or without helpers. The average number of eggs laid, hatched and young fledged was calculated. The student-t-test was applied to judge the significance of the results.

\section{Results}

The number of nest of the Black ibis in the study area was 26 during the normal season in 2003 as compared to the 14 nest during the drought in 2006 (Table 1). The average clutch size was $2.23 \pm 0.88$, the hatching success $1.88 \pm 0.72$ and fledgling success $1.65 \pm 0.68$ in the normal breeding season of 2003. Out of 14 nests studied in the study area during drought in 2006 only 3 were having one helper each. They were the young's of the previous brood of the breeding parents identified on the basis of ring implanted at the stage of fledgling. These helpers were engaged in feeding the brooding female, nestling and fledgling, and defending the nest by alarming calls against the intruders. We observed that in a few nests, the helpers defended the nest by giving anti-predator vocalization. They were also seen to help the breeding female, nestling and fledgling in feeding. They were not found into helping in nesting and incubation.

The total number of eggs in all the 11 nests, without helpers was 15 . It was 6 in three nests with one helper. The average clutch size, number of young hatched and young fledged were respectively $1.33 \pm 0.1$, $1.2 \pm 0.14$ and $1.06 \pm 0.01$ in the nest of Black ibis without helpers while it was 2 , $1.66 \pm 0.01,1.33 \pm 0.01$ in the nest with one helper. The average clutch size, number of young hatched and young fledged were comparatively higher i.e. 2, 1.66, 1.33 respectively with one helpers than the average clutch size, number of young hatched and young fledged i.e. $1.33 \pm 0.1$, $1.2 \pm 0.14$ and $1.06 \pm 0.01$ in the nest without helpers, the nestling grew rapidly and all the chicks fledged earlier, compare to nest without helper. None of the nests helped were predated.

\section{Discussion}

The number of nest builds by the Black ibis is lower during drought as compared to normal season. Such a reduced nesting activity may be due to low secretion of estrogen under the stress of harsh environmental during draught. Our assumption lends support from the findings of Barfield (1971) and Lehrman (1965) who reported that environment regulate gonadotropic hormone secretion in birds. The number of nest without helper is higher compare to nest with one helper in the Black ibis inhabiting the arid zone of Rajasthan. This may be due to the lack of predators of this bird and limited population. Our findings of helpers in the Black ibis are similar to those of White ibis (Bildstein, 1993; Herring and Gwalik, 2007).

Moreover, our results also support Keast (1959) who reported that some birds do not reproduce during extreme drought as there endocrine control of reproduction depends upon rainfall. Contrary to some other birds (Skutch, 1961; Gadagkar and Venkataraman, 1990; Sridhar and Karanth, 
K.C. Soni, A.N. Sharma and V.C. Soni / Our Nature (2008) 6: 47-51

Table 1. Drought induced nepotistic behaviour in the Black ibis (Pseudibis papillosa)

\begin{tabular}{|c|c|c|c|}
\hline Season & $\begin{array}{c}\text { Normal season } \\
(2003)\end{array}$ & \multicolumn{2}{|c|}{$\begin{array}{l}\text { Drought season } \\
\text { (2006) }\end{array}$} \\
\hline $\begin{array}{l}\text { No. of nests/400sq. km. } \\
\text { (A) With helpers } \\
\text { (B) Without helpers }\end{array}$ & $\begin{array}{l}26 \\
00 \\
26\end{array}$ & $\begin{array}{l}14 \\
03 \\
11\end{array}$ & \\
\hline Total number of helpers & 00 & 03 & \\
\hline $\begin{array}{l}\text { ROLE OF HELPERS } \\
\text { Feeding the breeding female } \\
\text { Defending the nest } \\
\text { Incubating the eggs } \\
\text { Feeding the nestlings } \\
\text { Feeding the fledglings }\end{array}$ & $\begin{array}{l}00 \\
00 \\
00 \\
00 \\
00\end{array}$ & $\begin{array}{l}03 \\
03 \\
00 \\
03 \\
03\end{array}$ & \\
\hline $\begin{array}{l}\text { Clutch size } \\
\text { (i)Total number of eggs } \\
\text { (ii) Average clutch size }\end{array}$ & $\begin{array}{c}\text { Without helpers } \\
58 \\
(2.23 \pm 0.88)\end{array}$ & $\begin{array}{c}\text { Without helpers } \\
15 \\
(1.33 \pm 0.1)\end{array}$ & $\begin{array}{c}\text { With helpers } \\
6 \\
(2 \pm 0.0)\end{array}$ \\
\hline Hatching success & $1.88 \pm 0.72$ & $1.2 \pm 0.14$ & $1.66 \pm 0.01$ \\
\hline Fledgling success & $1.65 \pm 0.68$ & $1.06 \pm 0.01$ & $1.33 \pm 0.01$ \\
\hline
\end{tabular}

1993; Sharma, 2002; Gill, 2004; Round, 2006) the Black ibis does not have any helper during normal season. The role of helper Black ibis only during the drought may be interpreted as the auxiliary has a lower probability of being successful as a breeder in such a harsh season, when the prey population is predicted to be low. Our this assumption get supports from the findings of Brown (1974) and Sridhar and Karanth (1993) where they noted that helping was high among birds following poor monsoon than following good monsoon.

It was also observed that some helpers help the breeding Black ibis only in feeding the brooding female, nestling and fledgling and defending the nest. It may be understood as they may be too immature to perform the other roles. Helping results comparatively bigger clutch size, increase in the number of chicks hatched and fledged per nest. This may be possible because of the increased vigilance of the nest and increased frequency of food received by the chicks in the nest with helpers. The helpers reduced the probability of a nest being predated. Moreover, our these results support the findings of Stallcup and Woolfenden (1978) and Emlen (1978) who reported that bird pairs with helpers produce larger clutches and more young's.

The question why the helpers should help in a harsh season may be answered in the light of Hamilton's theory of kin selection or inclusive fitness (Hamilton, 1964). The theory explains that fitness comes not only from rearing ones own offspring but also comes from carrying for one genetic relative.

\section{Acknowledgements}

I am highly thankful to UGC, CRO, Bhopal for providing financial assistance for this work in the form of minor research project and to Prof. P.C. Frederick, Dr. K. L. Bildstein, and Dr. M.C. Coulter (SIS Group) for providing valuable literature and guidance. 


\section{K.C. Soni, A.N. Sharma and V.C. Soni / Our Nature (2008) 6: 47-51}

\section{References}

Arnold, K.E. and I.P.F. Owens 1998. Cooperative breeding in birds: a comparative test of the life history hypothesis. Proc. R. Soc. Lond. B. 265: 739-745.

Barfield, R.J. 1971. Gonadotropic hormone secretion in the female ring dove in response to visual and auditory stimulation by the male. J. Endocrinol. 49: 305-310.

Bildstein, K.L. 1993. White ibis, wetland wanderer. Smithsonian Institution Press, Washington and London

Brown, J.L. 1974. Alternate routes to sociality in jays with a theory of the evolution of altruism and communal breeding. Am. Zool. 14: 63-80.

Brown, J.L. 1987. Helping and communal breeding in birds. Princeton, New Jersey: Princeton University Press.

Cockburn, A. 1996. Why do so many Australian birds cooperate:social evolution in the corvida? In Frontiers of population ecology (Eds. R.B. Floyd, A.W. Sheppard and P.J. de Barrow). Melbourne: CSIRO. pp. 451-472.

Dow, D. 1980. Communally breeding Australian birds with an analysis of distributional and environmental factors. Ети 80: 121-140.

Duplessis, M.A. 1993. Helping behaviour in cooperatively breeding green wood hoopoes: selected or unselected trait. Behaviour 127: 49-68.

Edward, S.V. and S. Naeem 1993. The phylogenetic component of cooperative breeding in perching birds. Am.Nat.141: 754-789.

Emlen, S.T. 1978. The evolution of cooperative breeding in birds. In Behavioural ecology: an evolutionary approach (Eds. J.R. Krebs and N.B. Davis). Oxford. Blackwell.

Emlen, S.T. 1984. Cooperative breeding in birds and mammals. In Behavioural ecology: an evolutionary approach (Eds. J.R. Krebs and N.B. Davis). Oxford: Blackwell. pp. 305-339.

Emlen, S.T. 1991. Evolution of cooperative breeding in birds and mammals. In Behavioural ecology: an evolutionary approach (Eds. J.R. Kreb and N.B. Davis). Oxford: Blackwell; pp. 301-337.

Gadagkar, R. and A. Venkataraman 1990. Nepotistic bee eaters. Current Science. 59(9): 445-446.

Gill, S.A. 2004. First record of cooperative breeding in a Thryothorus Wren. Wilson Bulletin. 116: 337342.

Herring, G. and D.E. Gwalik 2007. Multiple nest tending behaviour in an adult female White ibis. Waterbirds 30(1): 150-151.
Keast, A. 1959. Australian birds: The zoogeography and adaptation to an arid continent. Biogeography and ecology in Australia 8: 89-114.

Kushlan, J.A. and J.A. Hancock 2005. The Herons. Oxford University Press, Oxford.

Lehrman, D.S. 1965. Interaction between internal and external environments in the regulation of the reproductive cycle of the ring dove. In Sex and Behaviour (Ed. F.A. Beach). Wiley, New York

Ligon, J.D. and D.B. Burt 2004. Evolutionary origins. In Ecology and evolution of cooperative breeding in birds (Eds. W.D. Koeing and J.L. Dickingson), Cambridge University Press, Oxford.

Polani, A. and M.A. Elgar 1994. Cooperative breeding in the Australian avifauna and brood parasitism by cuckoos (Cucculidae). Animal behaviour 47: 697-706.

Round, P.D. 2006. Cooperative provisioning of nestings in the White-crested Laughingthrush Garrulax leucolophus. Forktail 22: 89-90.

Sharma, A.N. 2002. Effect of helpers on breeding success of the Common babbler (Turdoides caudatus). Current Science 82(4): 390-391.

Skutch, A.F. 1935. Helpers at the nest. Auk 52: 257273.

Skutch, A.F. 1961. Helpers among birds. Condor. 63: 198-226.

Skutch, A.F. 1999. Helpers at birds nests: a worldwide survey of cooperative breeding and related behaviour. University of Iowa Press. Iowa City.

Soni, K.C. 2008. Study on the population, foraging, roosting and breeding activities of the Black ibis/Red napped ibis (Pseudibis papillosa) inhabiting the arid zone of Rajasthan. Ph.D. Thesis, M.D.S. University, Ajmer, Rajasthan, India.

Sridhar, S. and K.P. Karanth 1993. Helpers in cooperatively breeding small green bee eater (Merops orientalis). Current Science 65(4): 489490.

Stacey, P.B., and W.D. Koeing 1990. Cooperative breeding in birds: Long term studies of ecology and behaviour. Cambridge University Press. Cambridge: $633 \mathrm{p}$

Stallcup, J. A. and G.E. Woolfenden 1978. Family status and contribution to breeding by Florida scrub jay. Anim. Behav. 26: 1144-1156.

Woolfenden, G.E., and J.W. Fitzpatrick 1984. Demography of a cooperative breeding bird. Princeton University Press, NJ. 